\title{
AGAMA DAN FENOMENA KEGILAAN
}

\author{
I Wayan Budi Utama \\ Program Pascasarjana \\ Universitas Hindu Indonesia \\ Denpasar \\ e-mail: budi_utama2001@yahoo.com \\ I Gusti Agung Paramita \\ Fakultas Ilmu Agama dan Kebudayaan \\ Universitas Hindu Indonesia \\ Denpasar \\ e-mail: apsariparamita@yahoo.com
}

\begin{abstract}
Religion actually has the face of Janus (double), on the one hand religion can face hard and often cause many casualties. This happens when religion is used as a justification for violent acts by certain groups to exclude other distinct groups. On the other hand religion has a melancholic face as something cool reconcile. In this case religion is often used as a healer against madness that occurs in society. In Bali religion becomes a healer against those who experience mental distress eg through "malukat" or "mebayuh". Religion paved the way for penance as in the "guru piduka" ceremony. Religion also neutralizes those who experience trance (kerauhan) during the rituals at the temple in Bali. The incident was in the psychological view is considered experiencing madness. This paper explains the role of religion as a healer in Hindu society in Bali. Data collection was done by observation technique, interview, and document study. Analysis and exposure of data is done by descriptive interpretative, through approach of sociology of religion.
\end{abstract}

Keywords: Religion and madness

\begin{abstract}
Abstrak
Agama sebenarnya memiliki wajah Janus (ganda), di satu sisi agama bisa berwajah keras dan seringkali menimbulkan banyak korban jiwa. Hal ini terjadi ketika agama digunakan sebagai alat pembenar terhadap tindakan kekerasan oleh kelompok tertentu untuk meniadakan kelompok lain yang berbeda. Di sisi lain agama memiliki wajah melankolis sebagai sesuatu yang sejuk mendamaikan. Dalam hal ini agama sering digunakan sebagai penyembuh terhadap "kegilaan" yang terjadi dalam masyarakat. Di Bali agama menjadi penyembuh terhadap mereka yang mengalami keguncangan jiwa misalnya melalui "malukat" atau "mebayuh". Agama memberi jalan bagi penebusan dosa seperti dalam upacara "guru piduka". Agama juga menetralisir mereka yang mengalami trance (kerauhan)
\end{abstract}


pada saat ritual di Pura di Bali. Peristiwa tersebut tadi dalam pandangan psikologi dianggap sedang mengalami "kegilaan". Tulisan ini menjelaskan peran agama sebagai penyembuh dalam masyarakat Hindu di Bali. Pengumpulan data diakukan dengan teknik observasi, wawancara, dan studi dokumen. Analisis dan paparan data dilakukan dengan deskriptif interpretatif, melalui pendekatan sosiologi agama.

Kata Kunci : Agama dan Kegilaan

\section{Pendahuluan}

Fenomena yang berkembang dalam masyarakat Hindu di Bali belakangan ini adalah semakin banyak orang atau sekelompok orang yang mengalami gangguan kejiwaan. Menurut informasi yang disampaikan oleh Suryani Institut for Mental Health memperkirakan ada sekitar 7.000 orang mengalami gangguan jiwa. Penyebabnya bisa bermacam seperti bisnis yang gagal, persoalan rumah tangga, dan yang menarik adalah panggilan untuk menjadi Pemangku, atau dalam masyarakat Bali dikenal sebagai "ngiring". Peristiwa ini bisa terjadi melalui proses trance.

Ukuran yang digunakan dalam menentukan kegilaan seseorang dalam pandangan jaman klasik adalah rasional. Ketika perilaku mereka dipandang berlawanan dengan akal sehat, maka distigmakan sebagai kegilaan - sesuatu yang patalogis (Foucoult, 2002). Ia merupakan sesuatu "yang lain " the others" dari suatu komunitas masyarakat (Jaya Kumara, 2009).

Sesuatu "mereka" bukan "kita". Pertanyaan yang kemudian muncul adalah bila akal sehat bisa memberi vonis apa yang masuk akal dan apa yang tidak, tentu ia dapat menjawab mengapa muncul kegilaan itu. Nyatanya akal sehat tidak mampu melakukannya. Dengan kata lain akal sehat tidak mampu memberi penjelasan atau menjawab penyebab tunggal sebagai prasyarat penyembuhannya.

Di Bali, agama lokal memberikan ruang penyembuhan bagi mereka yang dikategorikan sebagai mengalami kegilaan oleh pandangan rasional. Agama dan tradisi Bali menganggap mereka yang distigma gila sebagai 'kita' bukan 'mereka'. Bagaimana agama berperan dalam memberikan penyembuhan terhadap kegilaan tersebut menjadi fokus bahasan dalam tulisan berikut ini.

\section{Pembahasan}

Robertson (1986) menyatakan bahwa salah satu gejala intelektual yang paling menarik pada abad ke-20 adalah besarnya minat untuk mempelajari agama, dan pada suatu ketika terdapat kesesuaian pendapat secara luas bahwa kepercayaan agama sebagaimana difahami secara tradisional, secara mencolok lebih menekankan makna intrinsiknya bagi sebagian besar warga masyarakatat modern. Memperhatikan perkembangan studi agama-agama dewasa ini dapat dikelompokkan menjadi dua pendekatan.

Pendekatan yang pertama bersifat teophosentris, yaitu menelaah agama sebagai seperangkat ajaran-ajaran dari Tuhan yang tercantum dalam kitab-kitab suci. Agama dipandang sebagai seperangkat keyakinan yang sakral dan mutlak, yang mengatur hubungan manusia dengan Tuhan, manusia dengan sesamanya, dan manusia dengan alam lingkungan di mana ia berada. Studi agama seperti ini bersifat sangat normatif atau dengan kata lain menggunakan pendekatan yang bersifat tekstual. Pada 
dimensi ini agama diletakkan sebagai standar moral dan acuan sopan santun tingkah laku sosial budaya. Agama dalam hal ini dipandang sebagai pusat-pusat orientasi nilai yang memiliki kebenaran analistis-ideologis.

Sementara itu, pendekatan kedua, agama ditelaah sebagai kenyataan yang bersifat sosio-historis yang tumbuh dan berkembang dalam pengalaman perilaku para pemeluknya. Dalam pendekatan ini agama lebih dimaknai dalam konteks kehidupan dan kebudayaan para pemeluknya. Pendekatan ini lebih bersifat kontekstual atau lebih bersifat empirik.

Di dalam praktik ini kebenaran agama secara tekstual mendapatkan nilai tertingginya karena kebenaran agama lebih ditekankan pada praktiknya dan bukan hanya dalam kebenaran normatifnya. Harus diakui bahwa tidak setiap kebenaran secara normatif selalu sama dengan kebenaran agama secara praksis dalam kehidupan sosial karena pada kenyataannya tidak ada ide yang eksis dalam realitas empiris. Akan tetapi setidak-tidaknya agama memiliki dua dimensi penting bagi manusia, yakni menata pemikiran dan sikap manusia dan juga menata tindakannya dalam berbagai aspeknya.

Dalam sebuah artikel di media sosial dijelaskan bahwa fenomena kerahuan (trance) dapat dikategorikan menjadi tiga. Pertama adalah mereka yang pura-pura kerauhan. Dalam kategori ini kebohongan sengaja dilakukan untuk mencapai tujuantujuan tertentu yang menguntungkan dirinya sendiri. Masyarakat yang masih polos dengan mudah diperdaya oleh segelintir orang dengan memanfaat kepolosan ini. Kedua, mereka yang benar-benar kerauhan.

Walaupun mulai jarang, namun memang ada mereka yang benar-benar kerauhan dalam artian benar-benar ada entitas niskala yang memasuki dirinya.
Ketiga, mereka yang mengira dirinya benar kerauhan padahal tidak. Kelompok ketiga ini adalah fenomena neuro-psikologis semata mulai dari yang sangat sederhana yaitu abreaksi dari pikiran bawah sadar, atau yang lebih parah yaitu dissasociative Trance and Possesion dan bahkan Scizoprenia (Bali Wisdom, 17 May 2017). Dalam pandangan Fauzi (2011) Scizoprenia bisa terjadi karena kesadaran telah dikooptasi oleh kekuatan material dan naluri kesenangan yang distortif.

Praktik agama lokal di Bali memberi akomodasi terhadap perilaku "kegilaan" yang dijelaskan sebelumnya. Ritual-ritual yang dilaksanakan seperti piodalan, mebayuh, malukat menjadi bagian tak terpisahkan dari kegilaan yang dialami masyarakat. Setiap hari-hari baik untuk melaksanakan ritual seperti purnama, tilem, kajeng kliwon, anggara kasih dan lain sebagainya; tempat-tempat melakukan ritual penyembuhan seperti sumber mata air (laut, pancuran, mata air) menjadi tempat favorit untuk dikunjungi.

Ada satu cerita menarik yang diungkapkan oleh seorang penderita skizofrenia di Bali, sebut saja Made Wijaya (bukan nama sebenarnya). Beberapa tahun yang lalu ia mengalami peristiwa tidak lazim. Ia mengaku sering didatangi orang tidak dikenal. Menurut cerita Made orang itu mengatakan bahwa dirinya adalah salah satu titisan dari seorang Pendeta dari Jawa yang datang ke Bali.

Pendeta itu adalah Dang Hyang Nirartha yang juga dikenal dengan nama Dang Hyang Dwijendra. Sejak ada suarasuara itu, Made Wijaya jadi sering mengasosiasikan dirinya sebagai titisan Dang Hyang Dwijendra. Hal itu dia alami setiap hari selama beberapa tahun. Sejak saat itu pula Made Wijaya merasa memiliki multi kepribadian - ada saat-saat dia menganggap diri sebagai Dang Hyag 
Dwijendra.

Upaya pengobatan sudah dilakukan, salah satunya dengan melakukan konsultasi rutin dengan ahli ilmu jiwa. Namun tak kunjung sembuh. Ia masih saja mendengar suara-suara aneh dan melihat orang yang sering muncul di hadapannya. Sampaisampai, Made Wijaya harus dibawa ke Rumah Sakit Jiwa. Setelah sempat masuk ke Rumah Sakit Jiwa, relasi sosialnya mulai berubah. Ia dicap gila dan dianggap 'orang tak normal'.

Bisa dikatakan, secara sosial Made Wijaya 'diliyankan' - dianggap orang lain yang berbeda dengan orang normal menurut ukuran akal. Tekanan sosial yang dia alami dengan stigma 'orang gila' justru memperparah kejiwaannya. "Akhirnya saya memutuskan untuk tidak melakukan kontak dengan orang lain," cetusnya.

Memang, beberapa terapi mental sudah ia jalani, termasuk mengikuti salah satu kelas spiritual. Namun, Made Wijaya mengaku lebih nyaman ketika ngayah di Pura Dalem. Setelah ngayah di Pura Dalem, Made Wijaya sering melihat hal-hal aneh. Tidak jarang ia malah kerauhan. Secara mengejutkan, Made Wijaya bisa menebak kejadian yang akan dialami oleh orangorang yang dia temui. Bahkan, ia mengaku pernah dirasuki salah satu Bhatara yang berstana di Pura Dalem.

Sejak itu, Made Wijaya justru mendapat perlakuan khusus dari masyarakat. Ia tidak dicap gila, melainkan orang yang 'dipilih' para dewa untuk menurunkan pesan. Pada akhirnya, Made Wijaya pun dikenal sebagai Jro Tapakan atau orang yang memiliki kemampuan mendatangkan dan berkomunikasi dengan Bhatara, termasuk roh leluhur.

Di sinibisa dilihat perbedaan perlakuan terhadap penderita 'kegilaan'. Agama tradisional justru lebih akomodatif terhadap fenomena kegilaan, bahkan memberi ruang asosiasi terhadap gejala tersebut. Berbeda dengan pandangan rasional yang membuat dikotomi normal dan tidak normal berdasarkan ukuran akal. Sesuatu yang tidak bisa dijelaskan oleh akal sehat justru dianggap tidak normal - patologis. Berbeda dengan agama yang tidak menganggap orang mengalami gangguan jiwa sebagai 'mereka', tetapi sebagai 'kita'.

Secara tekstual agama menata pemikiran manusia sehingga secara kontekstual ia tidak tersesat dalam dunia pengalaman yang sarat dengan kontradiksi nilai dan norma. Perpaduan antara agama sebagai kebenaran tekstual dan kontekstual merupakan ideologi tertinggi dari sebuah cita-cita keberagamaan dalam setiap masyarakat manusia.

Walaupun demikian, dalam dunia yang semakin sempit oleh karena pesatnya perkembangan informasi dan teknologi, baik agama maupun masyarakat telah mengalami perubahan. Fungsi agama dalam masyarakat juga mengalami pergeseranpergeseran yang semakin meyakinkan semakin jauh dari fungsinya semula karena kehadirannya tidak lagi dimonopoli oleh identitas yang bersifat kewilayahan. Identitas tidak lagi dapat ditemukan dalam batas-batas budaya masyarakat setempat karena arus barang dan orang semakin dinamis.

Dalam konteks pergeseran semacam ini simbol kebudayaan akhirnya, bukan lagi sebagai pengarah yang menentukan dalam suatu masyarakat yang dipatuhi dan memiliki daya paksa, tetapi menjadi alat politik bagi perjuangan kepentingan para pihak, baik individual, kelompok maupun institusi. Simbol-simbol agama misalnya, tidak hanya menjadi penunjuk arah dari suatu praktik yang berhubungan dengan religiusitas, tetapi juga bagi sebagian orang, kelompok atau institusi menjadi alat bagi legitimasi atas keberadaan dan kepentingan. 
Agama berfungsi mengesahkan keberadaan dan tindakan-tindakan yang bisa terjadi menyimpang dari substansi ajaran karena citra telah mewakili suatu realitas keagamaan itu sendiri. Agama dipraktikkan sebagai bagian dari pengendalian sosial dan identifikasi diri untuk pemosisian individu, kelompok, dan institusi dalam serangkaian transaksi sosial yang dinamis dan kontekstual. Simbol-simbol budaya telah menjadi alat bagi penegasan autentisitas kelompok yang keberadaannya menjadi bagian dari sistem sosial global dengan pertentangan nilai yang semakin tajam (Abdullah, 2006).

Sejalan dengan pandangan di atas, Cassanova (2003) mengasumsikan bahwa dalam skala global pada dekade tahun 1980an, agama menunjukkan wajah Janusnya, sebagai pembawa identitas-identitas yang tidak hanya eksklusif, partikularis, dan identitas-identitas primordial, namun juga inklusif, universal dan transenden. Kebangkitan agama menandai kemunculan fundamentalisme serta perannya dalam mencegah penindasan dan munculnya 'ketidakberdayaan'. Kondisi paradoks agama ini telah memunculkan berbagai konflik yang berbau agama. Artinya, agama sebagai pemicu konflik sosial pada dasarnya terletak bukan pada pengingkaran terhadap ajarannya, melainkan karena praktik agama yang terlalu ketat berdasarkan dogmadogma ajarannya.

Praktik agama yang demikian ketat ini tidak memberi ruang bagi perkembangan paham-paham keagamaan yang berbeda dalam satu agama sehingga tanpa disadari agama telah membentuk umatnya menjadi masyarakat munafik. Dikatakan demikian karena pada satu sisi agama memerintahkan umatnya melakukan hubungan pribadi dengan Tuhan melalui dogma dan peribadatan yang ketat. Sebaliknya, pada sisi lain sebagai akibat dari praktik yang demikian, seolah-olah agama memaksa umatnya untuk tidak peduli terhadap kehidupan sosial karena kehidupan akhirat jauh lebih penting daripada kehidupan di dunia ini.

Wajah ganda agama ini menurut Nottingham (1992) karena di satu sisi agama bisa merupakan fokus potensial bagi munculnya pembaharuan yang kreatif sekaligus juga kekacauan dalam masyarakat. Kondisi paradoks agama ini, sebagaimana digambarkan Nottingham dan Cassanova tersebut menurut Soemardjo (2003) fenomena agama dalam hidup umat manusia adalah bahwa agama mampu menyatukan manusia, tetapi agama juga dapat memecah belah manusia. Dalam satu agama berbagai bangsa dan kebudayaan dapat disatukan, tetapi dalam agama satu dengan agama yang lain seringkali mengakibatkan perpecahan, pertikaian, bahkan peperangan. Tidak jarang pula terjadi bahwa dalam satu agama, dalam arti berpegang pada satu kitab suci yang sama, karena perbedaan penafsiran mengakibatkan pula perpecahan dan pertikaian. Ini berarti agama, selain dapat menyatukan visi sosial suatu masyarakat, ternyata juga agama berpontensi menjadi pemicu konflik sosial. Konflik sosial ini bukan hanya terjadi dalam hubungan antaragama, tetapi juga dalam satu agama dengan paham keagamaan yang berbeda sehingga konflik internal begitu terbuka dalam setiap agama.

Dengan singkat dapat dikatakan bahwa agama memiliki dua wajah berbeda dan berlawanan, yaitu yang satu menyejukkan dan yang lainnya menyeramkan. Menyejukkan karena agama mengajarkan kesucian dan penyatuan dengan Tuhan yang ajarannya selalu berisi tema moral dan bertujuan keselamatan. Sebaliknya, menyeramkan karena ketika agama dilepaskan dari intinya dan dipraktikkan hanya sebagai ajaran dan karenanya kurang 
peduli terhadap dunia kontekstualnya.

Dari paparan tersebut di atas semakin tampak bahwa agama memang diperlukan dalam menata perilaku manusia. Hal ini menjadi penting karena pengalaman manusia yang diperoleh dari ketidak pastian, ketidakberdayaan dan kelangkaan yang memang merupakan karakteristik fundamental kondisi manusia. Dalam hal ini fungsi agama adalah menyediakan dua hal. Pertama, memberikan suatu cakrawala pandang tentang duania luar yang tak terjangkau oleh manusia, dalam arti di mana deprivasi dan frustasi dapat dialami sebagai sesuatu yang mempunyai makna. Kedua, menyediakan sarana ritual yang memungkinkan hubungan manusia dengan hal di luar jangkauannya, yang memberikan jaminan dan keselamatan bagi manusia mempertahankan moralnya ( O’Dea, 1985 ).

Untuk mampu mempertahankan eksistensi moralnya dari persoalanpersoalan yang dihadapi, manusia membutuhkan agama sebab menurut O'Dea (1985) agama paling tidak mempunyai 6 (enam) fungsi yaitu :

1. Agama mendasarkan perhatiannya pada sesuatu yang di luar jangkauan manusia yang melibatkan takdir dan kesejahteraan, menyediakan bagi pemeluknya suatu dukungan, pelipur lara dan rekonsiliasi. Manusia membutuhkan dukungan moral di saat menghadapi ketidakpastian, pelipur lara di saat berhadapan dengan kekecewaan dan rekonsiliasi dengan masyarakat bila diasingkan dari tujuan dan norma-normanya.

2. Agama menyediakan hubungan transendental melalui upacara dan pemujaan, yang mampu memberikan dasar emosional bagi rasa aman serta identitas yang lebih kuat.

3. Agama mensucikan norma-norma dan nilai-nilai masyarakat yang telah dibentuk, sehingga memposisikan dominasi tujuan kelompok di atas tujuan individual.

4. Agama juga mempunyai fungsi untuk mengkaji kembali nilai-nilai dan norma-norma yang telah terlembaga, bila memang masyarakat membutuhkannya.

5. Agama melakukan fungsi-fungsi identitas yang penting, melalui peranserta manusia di dalam ritual agama dan doa, sehingga mereka melakukan unsur-unsur signifikan yang ada dalam identitas.

6. Agama bersangkutpaut dengan pertumbuhan dan kedewasaan individu, dan perjalan hidup melalui tingkat usia yang ditentukan oleh masyarakat.

Ringkasnya secara fungsional, agama mengidentifikasikan individu dengan kelompok, menolong individu dalam ketidakpastian, menghibur ketika dilanda kecewa, mengaitkannya dengan tujuantujuan masyarakat, memperkuat moral, dan menyediakan unsur-unsur identitas.

Terkait dengan persoalan kerahuan (khususnya kategori ketiga) yang dalam pandangan rasional dipandang sebagai sebuah kegilaan, agama memberikan akomodasi melalui berbagai ritual dan upaya penetralisir seperti mebayuh, malukat dan lain sebagainya. Namun demikian agama juga tidak menerima begitu saja mereka yang mengalami kerauhan tersebut. Berbagai cara untuk menguji kebenarannya juga dilakukan oleh masyarakat. Ada yang menyiapkan api unggun yang terbuat dari batok kelapa, menyiapkan keris serta upaya lainnya untuk menguji kebenaran fenomena kerauhan tersebut. Hal ini banyak membantu mengurangi jumlah mereka yang memanfaatkan fenomena kerauhan untuk hal-hal yang tidak diinginkan. 


\section{Penutup}

Berdasarkan uraian di atas dapat disimpulkan beberapa hal sebagai berikut. Pertama, bahwa ada tiga kategori kerauhan (trance) di Bali, khusus yang termasuk dalam kategori ketiga bisa dikatakan sebagai orang-orang yang mengalami persoalan kejiwaan (bisa dikatakan mengalami kegilaan). Kedua, agama lokal dalam hal ini fungsional dalam menangani persoalan kegilaan dimaksud melalui ritual-ritual yang disediakan. Ketiga, agama lokal di Bali di samping memberikan akomodasi juga memberikan jalan bagi uji kompetensi terhadap mereka yang melakukan kebohongan dalam kerauhan, ada yang dengan jalan menyiapkan api unggun, dan cara-cara lain yang akhirnya bisa menyadarkan kembali yang bersangkutan.

\section{DAFTAR PUSTAKA}

Casanova, Jose. 2003. Agama Publik Di Dunia Modern: Public Religion in the Modern World. Surabaya: Pustaka Eureka; Malang: ReSIST, dan Yogyakarta: LPIP.
Fauzi, Ahmad. 2011. Agama Skizofrenia. Delusi, Ketidaksadaran dan Asal-usul Agama. Semarang: Lembaga Studi Sosial dan Agama.

Foucoult, Michel. 2002. Kegilaan Peradaban, Madness and Civilization. Yogyakarta: Ikon Teralitera.

Jaya Kumara, I Gede. 2009. Sarad. Denpasar: Majalah Gumi Bali no 106 Februari 2009.

Nottingham, Elizabeth K. 1992. Agama dan Masyarakat. Jakarta : Rajawali Press.

O’Dea, Thomas F. 1985. Sosiologi Agama. Jakarta: CV. Rajawali.

Robertson, Roland. 1986. Sosiologi Agama. Aksara Persada Offset. 